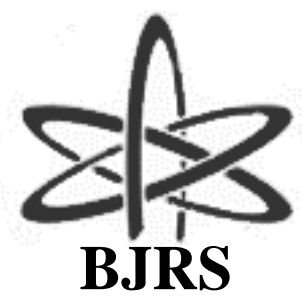

\author{
BRAZILIAN JOURNAL \\ $\mathrm{OF}$ \\ RADIATION SCIENCES \\ 07-02A (2019) 01-17
}

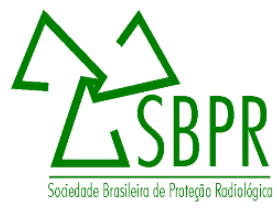

\title{
Concrete containers in radioactive waste management: a
}

\section{review}

\author{
Tavares $^{\mathrm{a}}$ B.L., Tello ${ }^{\mathrm{a}}$ C.C.O. \\ ${ }^{a}$ Centro de Desenvolvimento da Tecnologia Nuclear (CDTN / CNEN) / Av. Presidente Antônio Carlos, 6.627 - Campus \\ da UFMG, 31270-901,Belo Horizonte, Minas Gerais, Brazil. \\ barbaralacerdat@gmail.com \\ tellocc@cdtn.br
}

\begin{abstract}
Nuclear power is considered a clean energy because it does not produce the gases responsible for greenhouse effect. However, like all human activities, it is susceptible to the generation of waste. With the increasing demand for energy in Brazil, the use of nuclear power is being expanded. With this, the implementation of proper treatment and disposal have become a necessity in order to ensure the non-contamination of the public or environment and that the exposure doses are lower than the limits determined by legislation. Most of the waste produced in Brazil is classified with low and intermediate radiation levels; consequently, the national repository will be near surface, in accordance with the legislation. Considering the multi-barrier concept for the repository, the radioactive waste product is the first barrier. To have a qualified radioactive waste product, it should be solid or solidified using an inert material. With the intention to standardize the disposal process, all radioactive waste products will be placed in concrete containers. These containers will be settled in a concrete cell, which is the final engineered barrier of the repository. The state of the art is the first part of the study of the concrete containers and its specific criteria acceptation. Tests still need to be performed in order to ensure the stability and resistance of the material, since the repository's operational and surveillance period is 60 and 300 years respectively.
\end{abstract}

Keywords: radioactive waste management, repositories, concrete containers.

ISSN: 2319-0612

Accepted: 2018-11-02 


\section{INTRODUCTION}

Since the generation capacity of nuclear power is superior to other thermic sources, and the fact that it does not produce the gases responsible for greenhouse effect, it has become one of the most important technologies to the future of the energy industry. For those reasons, after the Paris Agreement - signed by 188 countries in 2015, aiming for the reduction of these emissions - several emergent countries started encouraging the energy production by nuclear reactors. Meanwhile, countries that already have the technology in large scale, search for methods to make it even more sustainable as a way to contribute with the environment [1].

In 2016, among the 30 countries that have nuclear power, 66 new plants were under construction. With a world capacity of $384 \mathrm{GW}$, coming from 442 nuclear reactors (11\% of the global demand of energy), the most amount of energy is produced in the United States (33\%) and France (17\%). Considering the world nuclear energy production, the Brazilian contribution is only $0.6 \%$, which corresponds to $3 \%$ of the total demand of the country [1].

Brazilian legislation has established that the Government has the exclusive capability to control the complete fuel cycle (mining, enrichment, operating nuclear energy services and facilities as well as nuclear power plants), including activities as research, industrialization and trade in nuclear ores [2].

The National Commission for Nuclear Energy (in Portuguese, Comissão Nacional de Energia Nuclear, CNEN), a federal organization, was created to be in charge of all nuclear activities in Brazil. It has two divisions: the Directorate Radiation Protection and Nuclear Safety (DRS), responsible for regulating, licensing and controlling the nuclear activities concerning nuclear safety, security and safeguards; and the Directorate for Research and Development (DPD), responsible for research, development, production of radioisotopes and for receiving and disposing radioactive waste from Brazil [3].

Brazil has two operating power plants, Angra 1 and Angra 2, and another, Angra 3, under construction [4], with completion scheduled for 2026 [5]. All three plants are located in the same area named Central Nuclear Almirante Álvaro Alberto, in Angra dos Reis, State of Rio de Janeiro [4].

According to the 2010 national energy plan [6], by the year 2050 the country will have around $90 \%$ of its population living in urban areas, drastically increasing the demand for energy [7]. For this 
reason, Brazil needs to expand the energy supply combining three sources: natural gas, coal and nuclear. It was established that the increase of nuclear power will be achieved by the construction of 4 to 8 new nuclear plants, by the end of 2030, located in Northeast and Southeast [6].

Even though it is considered a clean energy and a better substitute for non-nuclear techniques when applicable, its use is not exempt from the generation of waste, which comes from the nuclear fuel cycle, medical, research and industrial activities, involving radioactive materials and also from the decommissioning of nuclear facilities [8].

Radioactive wastes are classified differently according to each country, but most of them are divided by the half-life (short, intermediate and long), radionuclide concentration (low, intermediate, high) and decay type (alpha, beta, gamma or neutrons) [8]. This classification allows the establishment of a universal language among those who constantly manage radioactive waste [9]. According to the IAEA (International Atomic Energy Agency) Safety Glossary: "waste is for legal and regulatory purposes, waste that contains, or is contaminated with, radionuclides at concentrations or activities greater than clearance levels as established by the regulatory body".

Waste management aims to process the waste in a way that it becomes proper for its final disposal, keeping it isolated from the environment. The "RBMN Project" was launched in Brazil in 2009, aiming for the construction of the repository for low and intermediate level waste, which is the final solution for the disposal of radioactive waste in the country. The concept for this repository is the near surface disposal, with a multi-barrier system, including the waste package, the concrete containers, the backfill, the concrete cell and the natural barrier [9]. This paper presents a review of the different concrete containers used for radioactive waste disposal in operating facilities in some locations of the world. It also is related to the Projeto RBMN (Action PPA 13 CM e PA 0598) as well as to Projeto de P\&D\&I, Deposição de Rejeitos Radioativos (0521-02).

\section{WASTE MANAGEMENT}

In Brazil, radioactive wastes are classified in accordance of their activity content and the half-life of the radionuclides [10]:

- Class 0: Exempt waste: waste with radionuclides which activity is below or equal the level of exemption 
- Class 1: Very short lived waste: waste with radionuclides which half-life is below or in the order of 100 days and with level of activity above the level of exemption

- Class 2: Low and Intermediate level waste: waste that radionuclide half-life is above the wastes from Class 1 and which the activity is above the level of exemption as well as thermal power below $2 \mathrm{~kW} / \mathrm{m}^{3}$

- Class 2.1: Short-lived waste: low and intermediate level waste containing radionuclides with emissions beta/gamma that half-life is below or from the order of 30 years and which the amount of long lived radionuclides alpha emitters are limited to $3,700 \mathrm{kBq} / \mathrm{kg}$.

- Class 2.2: Waste containing natural radionuclides: waste from the extraction and exploration of oil, containing radionuclides from the uranium and thorium series which activity are above the level of exemption.

- Class 2.3: Wastes containing natural radionuclides: waste containing mineral, natural or industrialized raw materials, containing radionuclides from the uranium and thorium series which activity are above the level of exemption.

- Class 2.4: Long lived waste: waste not included in the 2.2 and 2.3 classes and with amount of radionuclides of long lived which exceeds the limits by classification as short-lived.

- Class 3: High level waste: waste with thermal power above $2 \mathrm{~kW} / \mathrm{m}^{3}$ and with concentrations of long lived which exceeds the limits by classification as short-lived.

The majority of radioactive wastes in Brazil are classified as low and intermediate level. These are not adequate for disposal after its use, needing solidification in an inert matrix. In Angra 1, low/intermediate level wastes are incorporated in cement, while in Angra 2 they are incorporated in bitumen [11]. Countries like France, Belgium, Spain and Argentina are discontinuing the use of bitumen after the final evaluation of the radioactive waste cycle, which made the use of cement more economically and safely feasible for disposal [12].

The process of waste cementation consists at mixing the waste (that may be in the form of solution, mud or solid) with the cement, obtaining a final product (also named waste product), which is a less polluting material that can be handled, transported and stored without contamination risks. After mixing, cemented waste plaster is poured in packaging, where it will solidify. These packages are transported to a temporary storage until it is sent to the repository [11]. 
For this type of waste (low/intermediate level) the recommended repository, and in accordance with legislation, is the near surface one [10], with multiple barriers, being the waste product the first one [13].

\subsection{Brazil National Repository}

Considering the multi-barrier concept for the repository, known internationally, the radioactive waste product is the first barrier [13]. The purpose of this barrier is to retain the waste in an inert material, avoiding the release of radionuclides to the environment during the transport and disposal, ensuring the stability and durability of the waste product. It also allows significant radionuclides decay before radiation could affect the public [14]. Brazil has a standard for packaging the radioactive waste as it is placed in several types of recipients, according to the type of material (solid or liquid) [15].

In order to standardize and optimize the disposal operation, all radioactive waste products (in all packagings) will be conditioned in concrete containers, making it possible for safety analysis. These containers will be placed in a concrete cell, the final engineered barrier of the repository. At the end of the operational phase these cells will be covered with natural layers, some permeable and others impermeable [9].

The Brazilian national repository will follow this concept, being the waste package conditioning in containers, and these in concrete cells, being the final coverage with natural barriers, as seen in the scheme below [9]. (Figure 1) 
Figure 1: El Cabril disposal scheme

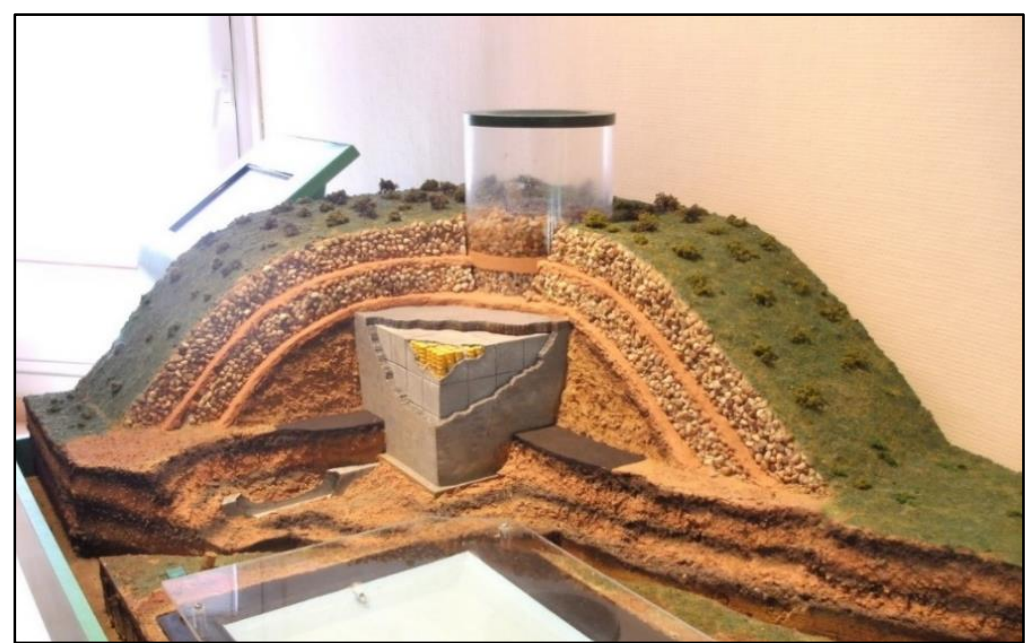

Source: Tello

\subsection{Concrete containers}

The containers should comply with specific criteria for near surface disposal of radioactive waste, once the repository will have an operational period of 60 years before the final covers [3] of mortar or concrete, clay and gravel. This way, the concrete containers should resist to impacts and leaching [16].

The Portland cement (CP) is the binder that will be used in the concrete to produce these containers. It is compound by clinker, which is present in all CP, and admixtures, that may vary from a cement to another [17] and define which type it is according to Table 1 [18].

Table 1: Types and characteristics of Portland cement [18]

\begin{tabular}{c|c|c|c|c|c}
\hline \multicolumn{7}{c}{ Content of components (\% in mass) } \\
\hline Type & $\begin{array}{c}\text { Initials } \\
(\text { BR })\end{array}$ & $\begin{array}{c}\text { Clinker }+ \\
\text { plaster }\end{array}$ & Slag & Pozolana & $\begin{array}{c}\text { Limestone } \\
\text { filler }\end{array}$ \\
\hline Common & CPI & 100 & & 0 & \\
\hline $\begin{array}{c}\text { Common with admix- } \\
\text { tures }\end{array}$ & CPI-S & $99-95$ & & $1-5$ & \\
\hline
\end{tabular}




\begin{tabular}{c|c|c|c|c|c}
\hline $\begin{array}{c}\text { Compound with slag } \\
\text { zolan }\end{array}$ & CPII-E & $89-56$ & $11-34$ & 0 & $0-10$ \\
\hline $\begin{array}{c}\text { Compound with poz- } \\
\text { Compound with filler }\end{array}$ & CPII-F & $94-90$ & 0 & 0 & $0-10$ \\
\hline Blast furnance & CPIII & $65-25$ & $35-70$ & 0 & $0-10$ \\
\hline Pozzolan & CPIV & $79-50$ & 0 & $21-45$ & $0-5$ \\
\hline High-early strength & CPV-ARI & $100-95$ & 0 & & $0-5$ \\
\hline Sulfate resistant & RS & - & - & - & - \\
\hline Low hydration heat & BC & - & - & - & - \\
\hline White Portland cement & CPB & $100-75$ & - & - & $0-25$ \\
\hline
\end{tabular}

Source: ABCP

It is possible to improve the properties of the concrete [19], using admixtures, fillers and fibers [17], which are materials different from water, aggregates and cement, which are used as ingredients for concrete or mortar [19].

The admixtures can be classified according to its scientific or practical criteria: action or effect, respectively. The action classification is divided in chemical (modifies the kinetic of hydration process); physical, (modifies the superficial and interfacial tension of water - "water-air" and "watersolid"); or physical-chemical actions (both of the descripted simultaneously) [17]. The effect classification is based on application purpose [17]:

- Admixtures to improve the concrete workability: reduction plasticizers, air entraining, dispersing agents or fluidifier;

- Modifiers of mechanic properties: water reducing plasticizers

- Modifiers of concrete properties under special exposure conditions: air entraining;

- Set modifiers and shrinkage: retarder or accelerators

- Sealing: permeability reducing or water repellent

- Expansive: volume stabilizer, gas or foam generator.

Besides these, there are other types of admixtures with other applications, such as reduction of heat of hydration, improvement in transport or release of concrete or even the control of expansion, 
which characteristics are obtained from powdery materials as inert, cement, pozzolan or crystallization agents [17].

Fillers are finely divided grains with grading smaller than minor aggregates, obtained though pulverizing limestone, silica, basalt or carbonate materials [20]. They are also known as mineral admixtures [17]. The fillers are added to mortar, grout, concrete or other cemented materials to fill spaces between the aggregates [17], assisting to reduce shrinkage, improve workability or add economical bulk [20].

Fibers can be naturals or synthetic. Synthetic fibers are mostly made of steel or polypropylene [17]. Fiber reinforced concrete is a material made of concrete (any type of CP, but most of CPII and CPV-ARI), admixtures and contains randomly oriented fibers, which improve the concrete properties under impact loads, dynamic properties and fatigue strength [21]. (Figure 2)

Figure 2: Example of fiber reinforced concrete (illustrative picture) [22]

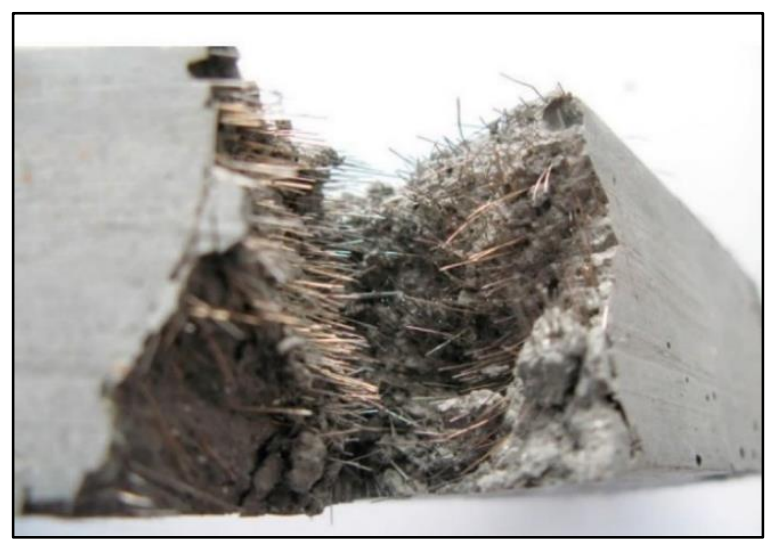

Source: SIKA website

These waste containers for the waste must have compressive strength between 25-35 MPa [23] and be able to resist to any impact caused by handling and transportation, as well as good leaching resistance for the whole period in the repository, not allowing significant radionuclide release to the environment [14]. In addition, high density which is directly connected to the porosity (and leaching): the higher the density and lower the porosity; the higher the compressive strength and leaching resistance will be [17]. 
The form and size of the containers are expected to be cubic with one side opening, and with an internal capacity of 3-6 $\mathrm{m}^{3}$. It will be made of precast concrete, using a steel mold. The cover plate will also be made the same way. This way, the parts can be manufactured in any location and only be transported to the Repository for storage and posterior use [24]. (Figure 3)

Figure 3: Example of precast container (illustrative picture) [24]

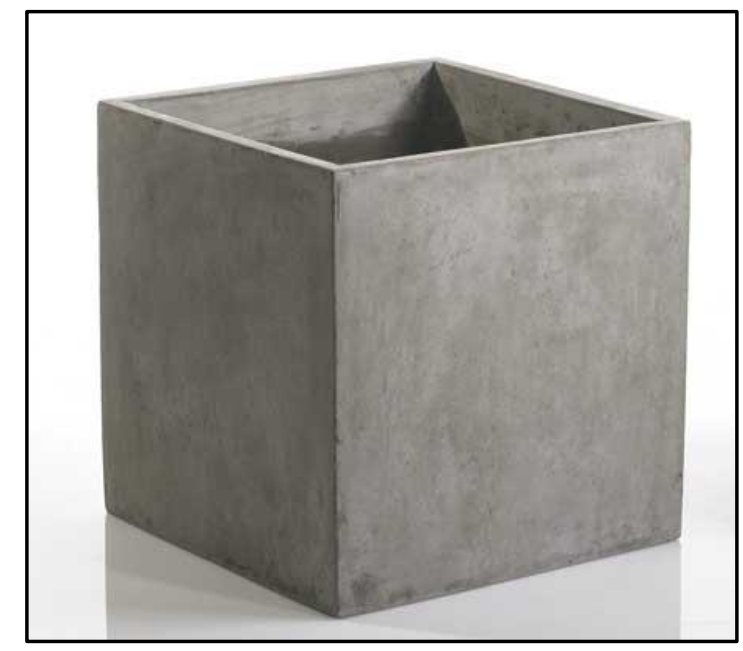

Source: Concreto \& Construções magazine

The quality of the concrete used is very important for good durability, technic and economical aspects [17], but the mix design, concrete mix, composition and technology have to ensure that the properties of the concrete will not change [19] during the operational time of 60 years [3].

After placing the waste product in the container, it will be filled with mortar, occupying the empty spaces and immobilizing the drums. Subsequently, the cover plate will lock the container, making it able to be transported to its final disposal in the concrete cell [13].

\section{INTERNATIONAL EXPERIENCE IN CONCRETE CONTAINERS FOR REPOSITORIES}

Concrete containers for conditioning radioactive waste packages are largely used in repositories [13]. A study of several repositories around the world, including Slovakia, Spain and United 
Kingdom, showed that some of them present similarities with the process chosen to be used in Brazil. A further study of the specific characteristics of these containers was then conducted.

\subsection{Slovakia}

The Slovakian radioactive waste repository Mochovce is a near surface one, constructed for the disposal of low and intermediate short-lived radioactive waste coming from the operation of all Slovak nuclear power plants and decommissioning of the A-I reactor [25]. The facility follows the multi-barrier concept, being the concrete container the primary protection in the whole system [26].

The material chosen for manufacturing the containers in Slovakia is the high performance fiber reinforced concrete (HPFRC), based on a French license [27], and modified according to its use. The fiber reinforced concrete is made of common cement with addition of fibers, in this case, metal strip fibers from FIBRALEX. The composition of these concrete containers are cement, gravel, sand, filler, silica fume, superplasticizer and water [26].

According to Hudoba [26], the internal capacity of the container is $2.9 \mathrm{~m}^{3}$, with dimensions shown in Figure 4, and it is made as a precast element in the bottom up position, using a steel mold. The fresh concrete is placed in the mold for 16 hours for curing. Later it is turned and the container is demolded.

Figure 4: Form and size of the container in Slovakia [25]

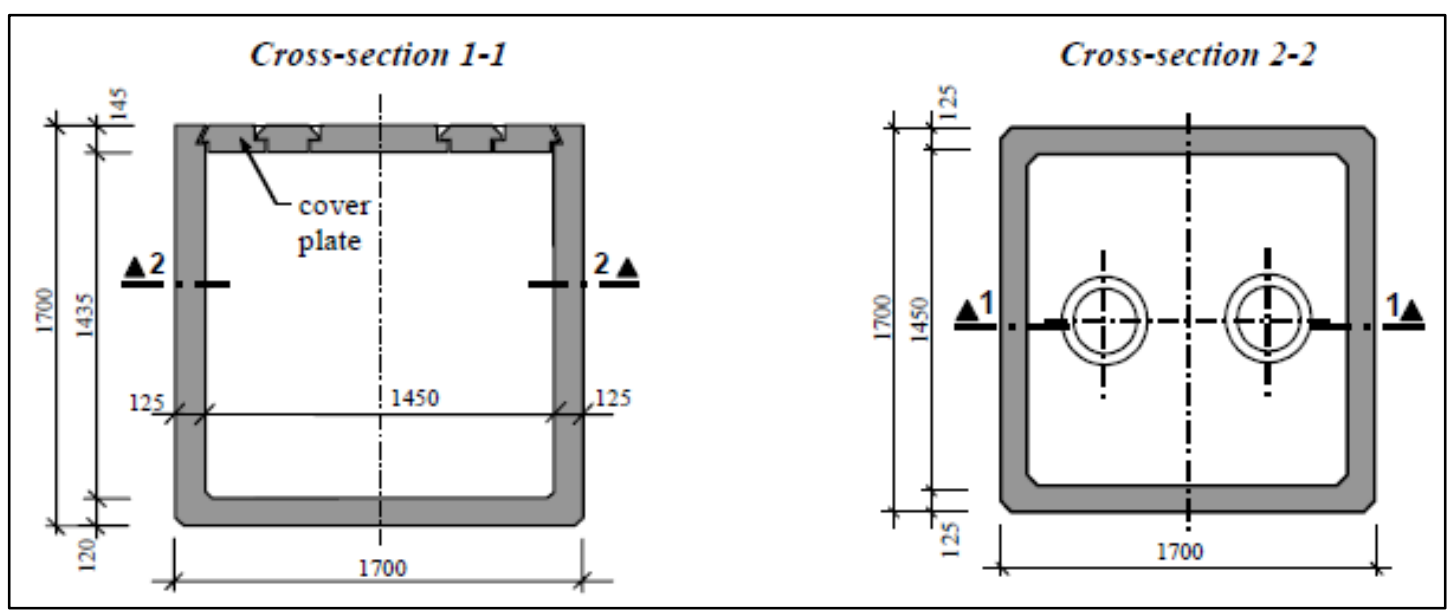

Source: Salzet, et. al. 
The packaging with the radioactive waste is placed into the containers and the inside of each one is immobilized with a cement paste. The full container is hermetically closed, transported to the storage place and stocked in the final disposal location [26].

\subsection{Spain}

The Spanish facility, El Cabril, is a near surface repository, to dispose of low and intermediate level waste arising from several activities such as nuclear power reactors operation, plants under decommissioning, the fuel fabrication plant and those coming from incidents occurred in non-nuclear industry [28].

The facility has its system of disposal based on the multi-barrier concept [13], composed by engineered and natural barriers, which will confine the radioactive material safely, ensuring the protection of people and environment [29].

Most of the waste produced in nuclear power plants arrive at El Cabril already conditioned in drums (waste package) [29]. According to Zuolaga [28], these packages are received and placed in concrete containers that, when at its full capacity, are immobilized by injected mortar, forming a compact block. Subsequently, it is deposited in the disposal vault (concrete cell). Once this structure is full, it is sealed with a flagstone made of reinforced waterproof concrete. After all the engineered structures are complete, it will be sealed with a final cover made of drainage and waterproofing layers, topped with a final layer of soil, allowing the integration with the environment.

The containers in Spain are made of reinforced concrete, with capacity for 18 packages of $200 \mathrm{~L}$ or 32 super-compacted pallets [28] (Figure 5). 
Figure 5: Concrete containers in El Cabril disposal facility [30]

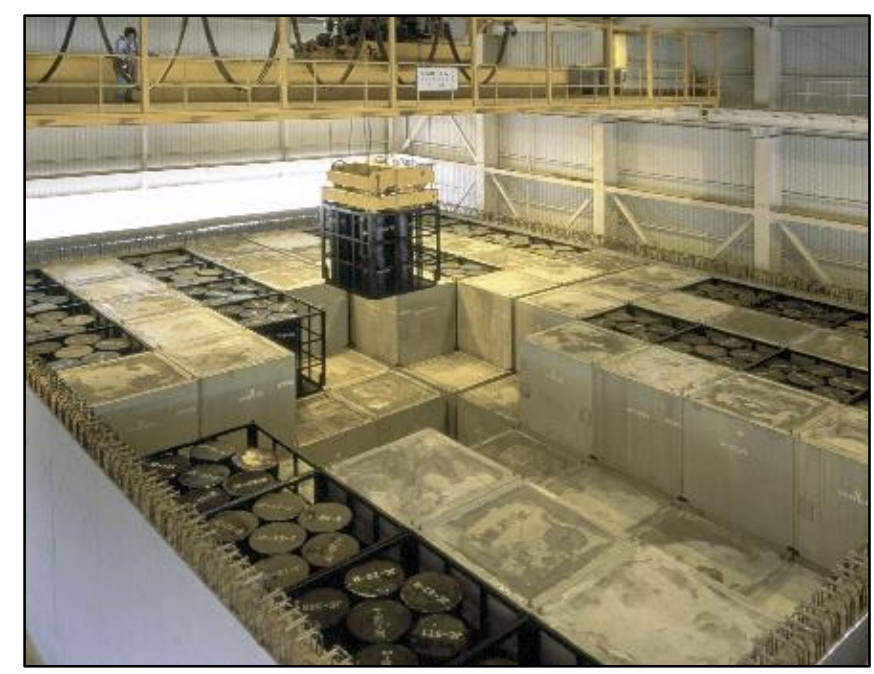

Source: ENRESA website

\subsection{United Kingdom}

According to the Waste Package Specification and Guidance Documentation, all nuclear facilities for disposal in the U.K. should use a concrete container for packing the waste product. The document includes a guide for applications in different waste packages specifications [31].

There is a specific one, that is in compliance with the requirements of Brazil, and it is the 6 cubic meter concrete box, which is made for low heat generating waste, compatible with the geological disposal of these wastes. This box was choosen since 2015, to be used for the packaging of wastes from the decommissioning of nuclear facilities [32].

According to the document [32], these containers are manufactured to be shielded waste packages, allowing the handling and safe transportation without remote techniques or additional protection, which is why it is made of reinforced concrete walls of approximately $24 \mathrm{~cm}$ thick. All containers have an identification, with 10 alphanumeric characters, located $7 \mathrm{~cm}$ of the lower surface (Figure 6). 
Figure 6: Standard features of the concrete container in United Kingdom [32]

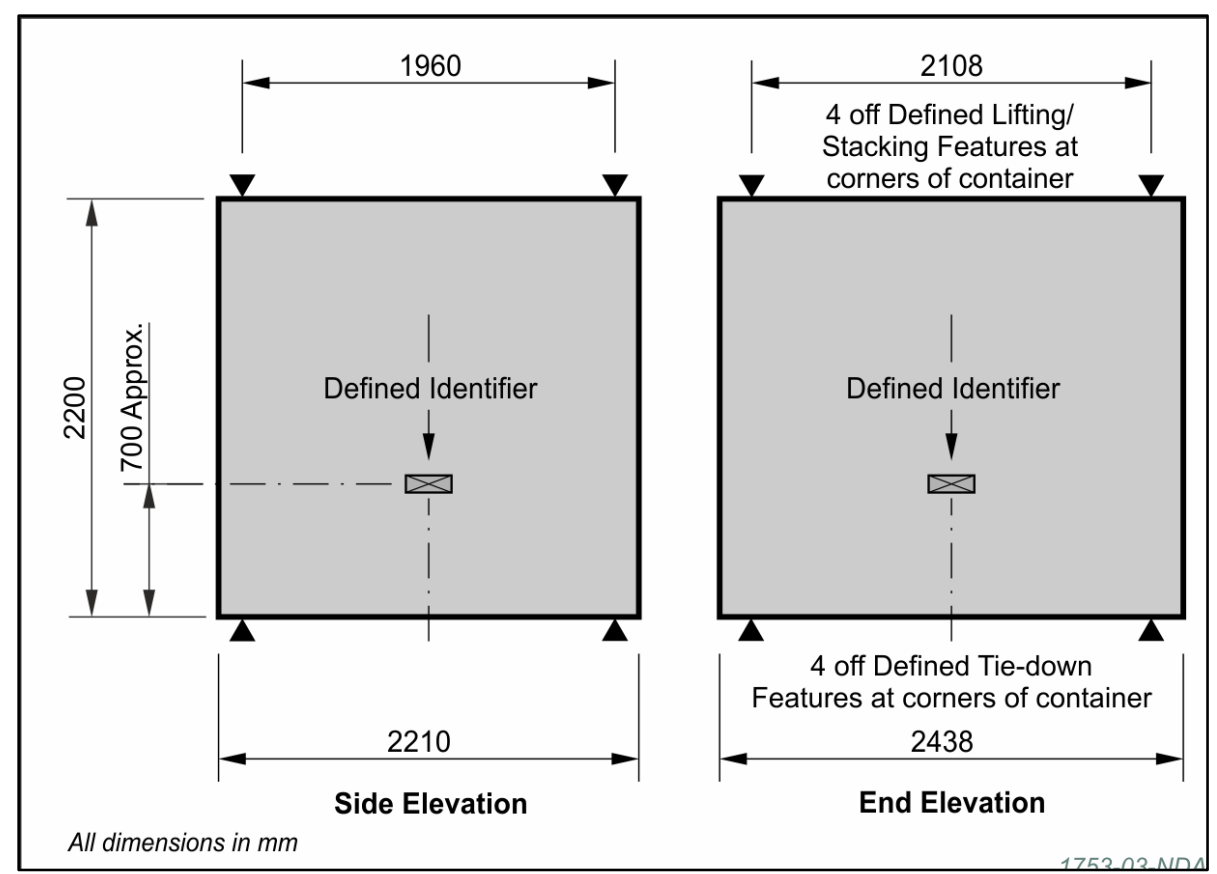

Source: Waste Package Specification UK

Still according to the document [32], some properties of the container are: it must be able to resist a compressive load equal to five times its own weight, to resist a compressive load of $2 \mathrm{MN}$, applied in the vertical axis of the container. Both of the efforts without showing any deformation or abnormality that may make it improper for transportation or any other requirements. Another property is the durability, since the operational period is of 150 years, it must be resistant to leaching, ensuring the integrity of the material. It also has specific requirements, as activity content, external doses and others, as shown in Table 2.

Table 2:Specific requirements of UK Government for disposal of radioactive waste in containers [32]

\begin{tabular}{l|c}
\hline \multicolumn{1}{c|}{ Requirement } & Limits \\
\hline Activity Content & $2 \times 10^{-3} \mathrm{~A}_{2 / \mathrm{g}}{ }^{*}$ \\
\hline External Doses & $0.1-10 \mathrm{mSv} / \mathrm{h}$ \\
\hline
\end{tabular}




\begin{tabular}{l|c|c}
\hline $\begin{array}{l}\text { Contammination of the sur- } \\
\text { face }\end{array}$ & $\begin{array}{c}<4.0 \mathrm{~Bq} / \mathrm{cm}^{2} \text { for beta, } \\
\text { gamma and low toxicity al- } \\
\text { pha emitters }\end{array}$ & $\begin{array}{c}0.4 \mathrm{~Bq} / \mathrm{cm}^{2} \text { for other alpha } \\
\text { emitters }\end{array}$ \\
\hline Heat generated & $60 \mathrm{~W}$ for transport & $30 \mathrm{~W}$ at the disposal \\
\hline
\end{tabular}

* unit of activity adopted by the IAEA Transport Regulations.

\section{CONCLUSION}

Using concrete containers in repositories to compose the multi-barrier system for near surface repositories is a system already applied in several countries. These containers are most used in order to standardize the packaging and the disposal process, reducing even more the radionuclides release to the environment and the risks for future generations. Besides, it also allows the establishment of a source-term, optimizing the safety analysis assessment.

Considering the countries studied, with repositories that already use the technology to conditioning waste packages, there is a pattern in what kind of structure and dimensions are used for its construction, being a cubic structure of reinforced concrete with walls between $1.7 \mathrm{~m}$ and $2.2 \mathrm{~m}$ the most chosen. In relation to radionuclide concentration and activity content, it varies according to the country's legislation.

Since this paper is only the first part of a further study, tests to confirm the resistance of these containers with local materials still need to be performed, as well as the requirement to use admixtures, fillers or fibers. Leaching tests are also a major requirement, in order to define the radionuclides concentration inside the containers and the activity content in the surface, providing a good product, capable of being transported without the use of remote techniques, which indicate exposure doses below the limits of the Brazilian legislation.

\section{ACKNOWLEDGMENT}

Appreciation to the Centro de Desenvolvimento da Tecnologia Nuclear (CDTN) and Fundação de Amparo à Pesquisa do Estado de Minas Gerais (FAPEMIG) for financial support. Also, to the orientation of Dr. Clédola Cássia and the help of my colleagues and workers from SEGRE. 


\section{REFERENCES}

[1] "Eletronuclear: Panorama da Energia Nuclear no Mundo," http://www.eletronuclear.gov.br/LinkClick.aspx?fileticket=SG_9CnL80wM\%3d\&tabid=406 (2016).

[2] "The National Commission for Nuclear Energy: National Report of Brazil 2014," http://www.cnen.gov.br/images/cnen/documentos/drs/relatorios-deconvencao/Waste_final_14.pdf (2014).

[3] "The National Commission for Nuclear Energy: Quem somos.” http://www.cnen.gov.br/quemsomos (2017).

[4] "Eletronuclear: Central Nuclear Almirante Álvaro Alberto." http://www.eletronuclear.gov.br/Aempresa/CentralNuclear.aspx (2017).

[5] "Agência Brasil: Angra 3 busca sócio privado para concluir construção". http://agenciabrasil.ebc.com.br/economia/noticia/2017-07/angra-3-busca-socio-privado-paraconcluir-construcao (2017).

[6] "Empresa de Pesquisa Energética: Plano Nacional 2030," http://www.epe.gov.br/PNE/20080111_1.pdf (2007).

[7] "Empresa de Pesquisa Energética: Demanda de Energia 2050," http://www.epe.gov.br/Estudos/Documents/DEA\%201315\%20Demanda\%20de\%20Energia\%202050.pdf (2016).

[8] IAEA, "Radiation, People and the Environment", IAEA, Vienna, Austria (2004).

[9] "International Atomic Energy Agency: Status of the implementation of Brazilian national repository," http://www.iaea.org/inis/collection/NCLCollectionStore/_Public/47/032/47032123.pdf (2015).

[10] CNEN, Licensing of storage and disposal facilities for low-and intermediate-level radioactive waste, Regulation CNEN-NN-8.02, CNEN, Rio de Janeiro, Brazil (2014).

[11] C. C. O. Tello, L. M. V. Barbosa, "Cimentação: Opção para Tratamento e Remediação", Congresso Brasileiro de Ciência e Tecnologia em Resíduos e Desenvolvimento Sustentável, ICTR/NISAM USP, Florianópolis, Oct.17-20, Brazil (2004). 
[12] C. C. O. Tello, V. Cuccia, "Experiência Internacional no uso da Betuminização como Processo de Solidificação de Rejeitos Radioativos”, CDTN, Belo Horizonte, Brazil (2011).

[13] C. C. O. Tello, Projeto de repositório para rejeitos radioativos de baixo e médio níveis de radiação, CDTN, Belo Horizonte, Brazil (2015).

[14] C. C. O. Tello, Waste Cementation - a Simple, Effective and Economical Waste Treatment, CDTN, Belo Horizonte, Brazil (2008).

[15] CNEN, Aceptation Criteria for Disposal of Low and Intermediate Radiation Level Waste CNEN-NN-6.09, CNEN, Rio de Janeiro, Brazil (2002).

[16] K. Brodén, S. Carugati, K. Brodersen, et. al, "Experiences of Storage of Radioactive Waste Packages in the Nordic Countries", NKS-32, Roskilde, Denmark (2001).

[17] L.A. F. Bauer, Materiais de Construção, Grupo Editorial Nacional, Rio de Janeiro, Brazil (2000).

[18] ABCP, Guia Básico de Utilização do Cimento Portland, ABCP, São Paulo, Brazil (2002).

[19] S. Mindess, J. Young, D. Darwin, Concrete, Prentice Hall, New Jersey, United States (2002).

[20] H. Farzam, ACI Committee 116, Cement and Concrete Terminology, ACI 116R-00, United States (2000).

[21] S. Mindess, "Fiber Reinforced Concrete: myth and reality," Advances in Cement and Concrete, (1994).

[22] “Sika: Fiber Reinforced Concrete Tecnology," http://mys.sika.com/en/concreteredirect/sika-concrete-technology/sika-sprayed-concrete-topics/requirements/fiber-reinforcedsprayed-concrete.html (2017).

[23] ABNT, Projeto de estruturas de Concreto - ABNT NBR 6118, ABNT, Rio de Janeiro, Brazil (2004)

[24] J. C. X. Andrade Filho, A. J. C. Silva, T. W. C. O. Andrade, "Pré-fabricados de concreto: cenário atual e necessidades especiais de produção e controle”, Concreto \& Construções, 59/38, pp.65-69 (2010).

[25] P. Salzer, V. Hanusik, L. Ehn, "Radioactive waste disposal in Slovakia: current practice and development", IEAE-CN, 90/26, pp.139-146 (20xx). 
[26] I. Hudoba, "Utilization of concrete as a construction material in the concept of Radioactive Waste Storage in Slovak Republic,” Acta Montanistica Slovaca, 12, pp.157-161 (2007).

[27] I. Hudoba, P. Greslík, "High Performance Fibre Reinforced Concrete as Attractive Material for Container Production in Radioactive Waste Management”, Symposium Keep Concrete Attractive, xx Budapest, pp.328-332 (2005).

[28] "Low and intermediate waste management in Spain," https://www.ipen.br/biblioteca/cd/inac/2002/ENAN/E05/E05_579.PDF (20xx).

[29] "Inernational Atomic Energy Agency: LILW acceptance procedures in spain: distribution of responsibilities," https://www.iaea.org/OurWork/ST/NE/NEFW/WTS-

Networks/DISPONET/disponetfiles/TM_WAP_France2012/TM_WAP_France2012-L4WastePackagesAcceptProcess_Vico.pdf (2012).

[30] “ENRESA: El Cabril Disposal Facility", http://www.enresa.es/eng/index/activities-andprojects/el-cabril (2017).

[31] "Government of United Kingdom: Radioactive Waste Management. Waste Package Specification and Guidance Documentation," https://www.gov.uk/government/uploads/system/uploads/attachment_data/file/461498/WPS640-Guidance-on-Monitoring-of-Waste-Packages-During-Storage-2008.pdf (2008).

[32] "Government of United Kingdom. Radioactive Waste Management. Waste Package Specification for 6 cubic metre concrete box waste package," https://www.gov.uk/government/uploads/system/uploads/attachment_data/file/485127/WPS_36 0_03_-WPS_for_6_cubic_metre_concrete_box_waste_package.pdf (2015). 